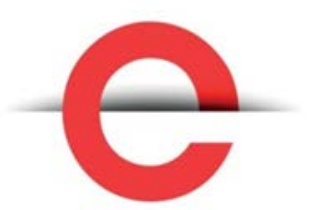

U T S

e P R E S S
Cosmopolitan

Civil Societies: an

Interdisciplinary

Journal

Vol. 9, No. 2

2017

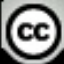

(C) 2017 Gary Levy. This is an Open Access article distributed under the terms of the Creative Commons Attribution 4.0 Unported (CCBY 4.0) License (https:// creativecommons.org/ licenses/by/4.0/), allowing third parties to copy and redistribute the material in any medium or format and to remix, transform, and build upon the material for any purpose, even commercially, provided the original work is properly cited and states its license.

Citation: Levy, G. 2017.Monday Mo(u)rning. Cosmopolitan Civil Societies: an Interdisciplinary Journal. 9(2), 72-78. http:// dx.doi.org/10.5130/ ccs.v9i2.5464

IS.SN1837-5.391 I Pı ıhlished by UTSePRESS|

mcs.epress.lib.uts.edu.au
COMMENTARY

\section{Monday Mo(u)rning}

\section{Gary Levy}

Deakin University, Burwood Campus, Melbourne, Australia

Corresponding author: Gary Levy, School of Education, Faculty of Arts and Education, Deakin University, Burwood Campus, 221 Burwood Highway, Burwood, Melbourne, VIC 3125, Australia. glevy@deakin.edu.au

DOI: http://dx.doi.org/10.5130/ccs.v9i2.5464

\section{Abstract}

This piece presents an imaginary scenario taking place in any typical primary school around Australia. It was developed for the special issue of Cosmopolitan Civil Societies Journal, on fake news and alternative facts, to show how these may arise in everyday practices.

\section{Keywords}

Fake news; alternative facts; truth; primary schools
DECLARATION OF CONFLICTING INTEREST The author(s) declared no potential conflicts of interest with respect to the research, authorship, and/or publication of this article. FUNDING The work was produced with no funding. 


\section{Monday Mo(u) rning}

Primary school teacher (PST): $\quad$ Good morning, children.

Children: Good morning, Mx!

PST: $\quad$ How are we all today?

Children: (various, muffled, and mingled responses)

PST:

Good to see everyone back again this week, bright-eyed and bushy-tail'd. Who has some news to share this morning?

Child A: $\quad$ My Nanna had to get rushed to hospital by ambulance, 'cos her heart wasn’t working properly.

PST:

Oh dear, how worrying! Is she being well looked after?

Child A: The doctors thought they'll have to do an operation, but now they think she just has to take some new pills.

PST:

Good to know. Well, next time you visit, tell her we are including her in our 'get well' thoughts each day.

Child A: $\quad$ Thank you, Mx; my Nan will be happy about that.

PST:

Who else has some news?

Child B: On Saturday, our dog ate the cat's breakfast, and then vomited all over my bedroom floor. The stink was so bad, I had to sleep that night on a mattress in my big sister's room.

Child C: $\quad$ Oh, yuk.

Child D: That's revolting!

Child E: $\quad$ That sounds like fake news to me.

PST: $\quad$ What do you mean, Child E?

Child E: $\quad$ I don’t believe him.

PST: $\quad$ But, what do you mean by 'fake news'?

Child E: $\quad$ 'Fake news'...it's like...some of the news you hear, like on TV and stuff, that you're not s'posed to believe, because someone else doesn't like the people who told that news. 
Child F: $\quad$ No, no....fake news is the news you hear that is still real, except it's not the same real for everyone.

Child E: $\quad$ Yeah, that's what I meant-that some news is just fibbing, or twisting things around a bit, or even lies, made up by the news-teller, to get more attention.

Child G: $\quad$ But, from what I've heard my mum and dad talk about, fake news is also....somehow...really fake...because....well...it's not the real news about something that actually happened, it's more like....hmmmnnn....I don't know...

PST:

Yes, children, you might have heard more people using the term 'fake news' lately- on TV, or the radio, or in conversation...Y You might have noticed that this 'fake news' is something that the new President Trump in America has been talking about a lot...

Child H: $\quad$ Yeah, and he's annoyed, because not everyone likes him, or says good things about him all the time, especially some people on the television, and newspapers and stuff like that, and that's why he's....

PST:

Well, that's an interesting observation Child H...How do you know he's annoyed and has those feelings about himself?

Child $\mathrm{H}$ : $\quad$ You can see it in his red and frowning face, and hear it in his achy and angry voice; and he's like other bullies that we talk about in class, who pick on other people because they are hurting too much inside themselves, but...

Child I: $\quad$ Yeah, so they have to make other people feel smaller and worser than they do...

Child H: $\quad$ Yeah, like...that's it...like...

Child J: $\quad$ But I thought we've learnt there are ways to work out what is 'true' and what is 'false', just like some things are 'right', and some things are 'wrong', and...

PST:

Well yes, we have talked about these differences, at times, and the importance of knowing good from bad, and right from wrong, so that...

Child: $\quad$ So that we have like, a society, and not just...

Child: $\quad$ Yeah, and, like some codes to help us organise and live our...

Child: $\quad$ Yeah, like morals and stuff... 
PST:

Very well done for remembering these things children! Yes, we have talked a lot about how, as a class of different individuals, with many small but important differences between each of us, we have to find ways to work together, to co-operate, trust, and respect one another, even if we don't always like one another, or when we sometimes disagree with each other. We have discussed many times how important it is for everyone to feel safe, and to be respected for who they are, and how we each have an equal right to express our beliefs and opinions, to find and use our own voice, without any

Child: $\quad$...without any fear of...

Child: $\quad$...of being teased, or embarrassed, or made to feel puny.

PST:

Yes, well done for remembering these important agreements we have made together, and that we revise and renew from time to time, in order to keep remembering what we have agreed to, and to keep that agreement strong and working for everyone's benefit...

Child X: $\quad$... and protection!

PST:

Yes, well done Child X-for everyone’s protection too...

Child Y: $\quad$ And isn't that, like protection, what the government here, and for Mr Trump, and in other countries too, isn't that what governments are saying they are doing for all the people? I mean, like, giving protection...

Child K: $\quad$ Yes but ...

Child L: $\quad$ Yeah but now, it seems, it's hard to know whether the dangers, and our fears, are real, or also just made up ones...

PST:

What do you mean, Child L?

Child L: $\quad$ I mean, like...well, from what my parents say, they reckon that, even though bad things are happening in the world, like, well, like all kinds of hating and killing and stuff, that, well, that even though these bad things are happening, now there are some political, um...politicians who, like, want people to be really worried, so that they can then pretend to be strong and like, be there to protect everyone, and stuff...

Child O: $\quad$ Yeah, and then like, but... 
Child Q: $\quad$ Yeah, so that means they can find new reasons to hate people, and prove they're super-strong by making wars, or stopping some people from.....

Child Y: $\quad$ But we do need big strong people to protect us against bad people, and like, isn't that what the government people are voted in to do?

Child K: $\quad$ Yeah, but we've been learning about 'making peace', instead of 'making war', and how hard that can be because in history and also now, fighting and winning fights always seems to be more important than being friendly with different people, and enjoying life together.

PST:

That's very well expressed, Child K. Maybe we need to send you along to meet some of the government people and tell them your ideas about these important things.

Child D: $\quad$ Yeah, except they probably wouldn't listen anyway, because we're only little, and haven't been to school for that long, and they might think we're just making stuff up and believing in things that aren't true anyway, like lots of kids have their own make-believe world...

Child L: $\quad$ Yeah, but my dad also reckons this is a big problem with the government people, because they kind of go more with just what they believe in, instead of getting to know the important facts about something.

PST:

That's interesting Child L...So, what do you think the difference is between fact, belief, and make-believe...

Child L: $\quad$ Hmmmnn...well, it’s like...well... I thought I knew this... but now...I'm not so sure, 'cos...

Child R: $\quad$ Well, I think I know, Mx...Facts, are, when...So, facts are when...

Child V: $\quad$ I know Mx....A fact is when something is true because, like, you can touch it, or see it, feel it, or prove that it is like, there...., or here...in some way, like...

PST: $\quad$ Ok, very good Child V... and so, how does a fact differ from a belief, or from make-believe, do you think....?

Child V: $\quad$ So, if facts are, like.... Oh, this is making my brain hurt Mx; do we have to talk about this anymore now....?

PST:

No, of course we don't Child V...Maybe we all need to leave this discussion alone for a while, and come back to it when we're feeling ready for more.

Child D: $\quad$ But before we finish Mx, can we try and work out the difference between facts and alternative facts, 'cos I've also heard those being talked about lately.

Child V: $\quad$ What? Alternative facts? Come on, Child D, now you must be making that up! 
Child D: $\quad$ No, no, it’s true, isn’t it Mx, or like real, or, I mean, like people are really talking about these, quote 'alternative facts', like they are different to other facts, but also...

Child V: $\quad$ Oh come on, this must be a joke! You must be kidding? These people must be like, looney or something....

Child S: $\quad$ Yeah, but how do we even know what's looney, and what's normal, when normal people are saying looney things...?

PST:

Well children, you amaze me with your thoughtful and really sharp comments and questions! Even though I'm your teacher, I certainly don't have any definite answers. I do need to say, however, that many of your points and questions are also being raised and discussed by concerned citizens here, but also in America, and in other countries too...

Child V: $\quad$ Mx.... How do we know who to believe or how to trust them, when there's all this blurring going on between truth and facts and beliefs?

PST:

That's another excellent question Child V, and one that is not so easy to answer. This is where we have to start applying some of the thinking skills that we have been developing and practising together. Who can remember the first step in this process....?

Child Q: $\quad$ Uhm...isn’t it...to....oh yeah, now I remember...the first step towards thinking clearly is to stop, to make some time and space, and not to try and know anything too quickly.

PST:

Very good, Child Q. Yes, we need to stop, not react too quickly, and give ourselves time to have a look at all the parts and angles of a situation and...

Child N: Yeah, that's right, to 'hasten slowly', so that we can get fully 'in the picture'.

PST: Very good, Child N, and then, gradually...

Child N: $\quad$ So, gradually, as we become more informed, we can start to get clearer and...

Child D: $\quad$ Yeah, clearer, and after becoming clearer, then we can start to understand the situation enough to ...

Child K: $\quad$... to then be able to shape a response. 
PST:

I'm very impressed with you lot, I must say, remembering these stages in the thinking process that we have worked on together-well done!

Child V: $\quad$ So then what about trust Mx, how do we get this happening more...?

Child X: $\quad$ You know Child V, once we have worked through the stages of thinking, we can trust our own judgement more, and then-like my dad says-we can 'sort out the sheep from the BS', or something like that...

Various children: (mixed laughter) Yeah the BS, good one!

Child V: $\quad$ So then, does that mean that we have to keep using our thinking skills, and trusting that these will help us get clear about where the real truth is, and what the lies are?

PST:

Well, yes Child V, you could put it that way....and it does appear that many people these days, including some of our politicians and leaders, have become lazy in their thinking, or have decided that they can get more of what they want if they think less, and stop many other people from thinking so much too.

Child Z: $\quad$ But Mx, if we stop thinking, doesn't our brain become like stodgy and weak from not being exercised enough...?

PST:

Well, yes, you could say that too, and well, you did say that...!

Children: (shared laughter)-Yuck, stodgy brains! Jelly brains! Thickheads! Wobbly wackos!

PST:

It is great that we can laugh about this children, while also knowing together that this unthinking is a big problem in the world today.

Child Q: $\quad$ Yeah, but if we keep practising our thinking skills, and lots of other kids in schools, even young ones, keep learning these skills, then more and more of us will be able to work out the difference between what's real and true, and what's fake and BS, right?

PST:

Well, gee...I would certainly like to think so Child Q... really, truly... my goodness.... I most certainly would like to think so....

Child S: Do you 'think so', as in real thinking and deep thinking, or 'think so' as in, like, 'believe whatever you want', kind of... 
Children: $\quad$ (much laughter) ...

PST:

No, I mean 'think so' as in, knowing and trusting that more and more children will learn, like you, how to develop their thinking skills, so that lies and fake news and other BS...

Children: (even more laughter, then chanting together): No more BS! No more BS! No more BS!...

If you don't think, your brain will stink! If you don’t think, your brain will stink! If you....

Grey matter, matters! Grey matter, matters! Grey matter, matters! Grey...

If you don’t mind, you lose! If you don’t mind, you lose! If you don’t...

Go more mental! Go more mental! Go more mental! Go more mental! Go...

Think, think more, think harder! Think, think more, think harder. Think... 